\title{
Ten Years of Initiatives to Promote Computational Thinking: A Systematic Mapping Study
}

\author{
Original Title: Um Mapeamento Sistemático Sobre as Iniciativas para Promover o \\ Pensamento Computacional
}

Júlia S. B. Ortiz, Roberto Pereira

Programa de Pós-Graduação em Informática, Universidade Federal do Paraná (UFPR) - Curitiba, PR - Brasil

\begin{tabular}{l} 
ARTICLE INFO \\
Article history: \\
Received 27 February 2019 \\
Accepted 07 April 2020 \\
Available online 05 May 2020 \\
\hline
\end{tabular}

Keywords:

Computational thinking Informatics in Education

Human-Computer Interaction

ISSN: $2595-9077$

DOI: JCThink.2019.v3.n1.p95

\begin{abstract}
INTRODUCTION: Computational Thinking is a problem-solving skill useful to everyone. Since its popularization, many initiatives have been conducted to develop this skill to students of several educational levels. OBJECTIVE: To determine the state of the art of initiatives carried out between 2007 and 2017 to promote Computational Thinking, inside and outside Brazil. METHOD: A systematic mapping study was conducted covering 3 stages of paper filtering to proceed with data extraction and analysis. Four databases were included to search papers published between 2007 and 2017, written in Portuguese or English. From a total of 468 papers, 46 remained in the final sample. RESULTS: Seven research questions were answered, showing that this topic of research has attracted researchers' interest, and the USA and Brazil stood out in the number of initiatives. However, the research conducted between these countries presented many differences regarding the duration of each research, the education levels of the students involved, and the tools used. CONCLUSION: Computational Thinking is a growing topic of research and knowing the initiatives published between 2007 and 2017 supports the elaboration of new research, mainly indicating opportunities to be explored. Especially in Brazil, it is necessary to address students beyond primary education, to explore the transdisciplinary potential of this skill, and to carry out longer initiatives with the students.
\end{abstract}

\section{Introduction}

Computational thinking (CT) is a problem-solving skill that involves concepts fundamental to computer science to address many problems of different natures (Wing, 2006). This ability has been studied by other researchers like Papert (1980), but the term "Computational Thinking" became popular after Wing's paper and ever since has gained visibility and attention of researchers in several areas, including outside computing. These researchers argue that CT is a useful skill for everyone, especially in modern times when it is becoming more and more common to use computing devices, which offer the most diverse services.

Besides the popularization of the term in the scientific community, the inclusion of programming disciplines in primary education of several countries, such as England, the United States and Australia, has fostered research on CT around the world. The many initiatives carried out aiming to develop CT as an essential skill reaches students from different levels of education and addresses different contents with different strategies and tools.

More than a decade has passed since Wing (2006) popularized the term, and it is necessary to map out the initiatives conducted to develop CT to draw the research scenario on the subject, both nationally and internationally. Besides mapping the initiatives to identify trends and opportunities for further research, a systematic mapping is a rigorous and reproducible study that offers a broader view for critical analysis and self-reflection of researchers.

Thus, this paper presents a systematic mapping of the literature to provide a summary of papers that describe initiatives conducted to promote CT. The mapping covered papers published between 2007-2017, on national and international bases, to 
investigate the initiatives' configuration such as: initiatives to promote CT are becoming frequent, which countries are researching this topic and which students' educational levels are being reached by the initiatives.

The extracted data demonstrate that since 2009 several papers describing initiatives to promote CT started to be published; the interest in this area is growing; the United States was the country with the largest number of publications, and that CT as a research topic is still in its first decade of study, presenting many opportunities and challenges for further research. The next sections present the related systematic mapping studies, the mapping process, the answers to the research questions, and the final considerations about this study.

\section{Computational Thinking}

In 2010, the Computer Science Teachers Association and the International Society for Technology in Education defined ${ }^{1} \mathrm{CT}$ as a problem-solving process that includes (but is not limited to) the following characteristics:

- Formulating problems in a way that enables us to use a computer and other tools to help solve them.

- Logically organizing and analyzing data.

- Representing data through abstractions such as models and simulations.

- Automating solutions through algorithmic thinking (a series of ordered steps).

- Identifying, analyzing, and implementing possible solutions with the goal of achieving the most efficient and effective combination of steps and resources.

- Generalizing and transferring this problem-solving process to a wide variety of problems.

In addition to the mentioned characteristics, the skills listed as understood by CT are: data collection, data analysis, data representation, problem decomposition, abstraction, algorithms and procedures, automation, parallelization and simulation (Barr and Stephensen, 2011).

\section{Related Systematic Mapping Studies}

To determine whether this study would present a broader scope about CT initiatives than what the literature already presents, a set of systematic mapping about the same topic was selected, in which the criterion were: conducted in 2016/2017, and published in the Brazilian Congress of Information Technology in Education (CBIE). Five literature reviews were identified, two studies published in 2016 and three studies published in 2017. An overview of all the studies found, including the present work, is presented in Table 1.

The first three studies in Table 1 sought to investigate specifically the Brazilian scenario, for having considered only in national events and journals such as the Brazilian Symposium on Informatics in Education (SBIE), and the Brazilian Journal of Informatics in Education (RBIE). Zanetti et al. (2016) conducted a systematic mapping to investigate CT initiatives in the context of programming teaching. Liz et al. (2016) conducted a systematic mapping to determine what are the methods used to stimulate

1 Available at: http://www.iste.org/docs/ct-documents/computational-thinking-operational-definitionflyer.pdf 
and evaluate CT. Carvalho et al. (2017) carried out a systematic review about the learning objects used to carry out CT activities.

\begin{tabular}{|c|l|l|l|}
\hline$\#$ & Authors & Time interval & Digital Libraries \\
\hline 1 & Zanetti et al. $(2016)$ & $2007-2015$ & SBIE, WIE, WEI e WAlgProg \\
\hline 2 & Liz et al. $(2016)$ & 2012 -july/2016 & SBIE, WIE, WEI, WAlgProg e RENOTE \\
\hline 3 & Carvalho et al. (2017) & $2012-2017$ & SBIE, WIE, WEI, RBIE e RENOTE \\
\hline 4 & Avila et al. $(2017)$ & 2011 -aug/2016 & IEEE, ACM, EBSCOhost e Science Direct \\
\hline 5 & Bordini et al. $(2017)$ & 2012 -aug/2016 & IEEE, ACM, Scopus, Science Direct e Springer \\
\hline 6 & Ortiz \& Pereira & $2007-2017$ & CEIE ${ }^{2}$, ACM, IEEE e Springer \\
\hline
\end{tabular}

Table 1. Related Systematic Mapping Studies.

Studies \#4 and \#5 covered international bases, which may cover both Brazilian and other countries' studies. Avila et al. (2017) conducted a systematic review of methodologies for assessing skills or dimensions of CT. Bordini et al. (2017) conducted a systematic review of CT initiatives in Elementary and High School.

Study \#6, the systematic mapping presented in this paper, differs from the formers presented because it has considered international and national digital libraries, searching for papers published in a broader period of time (from 2007 to November/2017), including all research that reports activities carried out to promote $\mathrm{CT}$, regardless of the target audience, the tools used, and the kind of activity carried out.

\section{Systematic Mapping of Literature}

The goal of this systematic mapping was to identify the initiatives that effectively present and discuss practices performed to promote CT. The mapping process was conducted following the guidelines of Petersen et al. (2015) and comprised the search for papers and application of the first, second and third filters. After the filters, data extraction and analysis were conducted to answer the research questions defined for this mapping, described below:

- RQ1: Which countries stood out regarding the number of initiatives?

- RQ2: Is the interest in conducting initiatives to develop CT growing?

- RQ3: Which students' educational levels are being addressed by these initiatives?

- RQ4: Are the initiatives addressing students in challenging contexts?

- RQ5: What contents were developed with CT in the activities conducted?

- RQ6: What tools were used in the activities?

2 The Special Commission on Informatics in Education library covers all articles published in the Brazilian Journal of Informatics in Education (RBIE), the Brazilian Symposium on Informatics in Education (SBIE), the Workshop on Informatics in School (WIE) and the Workshops of the Brazilian Congress on Informatics in Education (WCBIE) as the Workshop on Teaching Computer Thinking, Algorithms and Programming (WAlgProg). 
- RQ7: How long were the initiatives conducted with the students?

For the search, all the papers that have the terms Computational Thinking or "Pensamento Computacional" in their titles and that were published between 2007 and Nov/2017 were admitted, and the digital libraries selected for this mapping were $\mathrm{ACM}^{3}$, IEEE Explore ${ }^{4}$, Springer ${ }^{5}$ and Special Commission on Informatics in Education $\mathrm{CEIE}^{6}$ (Comissão Especial em Informática na Educação), according to their relevance for research in Informatics in Education from the perspective of Computer Science. The search period started in 2007 because it was after Wing's paper (in 2006) that the term became broadly used. The search conducted in November of 2017 returned 468 papers. Table 2 shows the number of papers found per digital library, and the search URL of each one.

\begin{tabular}{|c|c|c|}
\hline $\begin{array}{l}\text { Digital } \\
\text { Library }\end{array}$ & $\begin{array}{c}\text { Number of } \\
\text { Research Papers }\end{array}$ & URL \\
\hline $\mathrm{ACM}$ & 230 & $\begin{array}{l}\text { https://dl.acm.org/results.cfm?query=acmdlTitle:(\%22computational } \\
\text { \%20thinking } \\
\% 22) \& \text { within=owners.owner=HOSTED\&filtered=\&dte=2007\&bfr }=2017\end{array}$ \\
\hline IEEE & 102 & $\begin{array}{l}\text { https://ieeexplore.ieee.org/search/searchresult.jsp? } \\
\text { action=search\&searchField=Search_All\&matchBoolean=true\&queryText= } \\
\text { (\%22Document\%20Title\%22:.QT.computational } \\
\text { \%20thinking.QT.)\&highlight=true\&returnFacets=ALL\&returnType=SEA } \\
\text { RCH\&ranges=2007_2017_Year }\end{array}$ \\
\hline Springer & 75 & $\begin{array}{l}\text { https://link.springer.com/search?date-facet-mode }=\text { between } \& \text { facet-start- } \\
\text { year }=2007 \& \text { showAll=true } \& \text { facet-end-year }=2017 \& \text { dc.title }= \\
\% 22 \text { computational+thinking } \% 22 \#\end{array}$ \\
\hline CEIE & 61 & $\begin{array}{l}\text { http://www.br-ie.org/pub/index.php/index/search/search? } \\
\text { query=pensamento+computacional\&searchJournal=\&title=pensamento+co } \\
\text { mputacional\&dateFromMonth=01\&dateFromDay }=1 \& \text { dateFromYear=2007 } \\
\text { \&dateToMonth=12\&dateToDay=31\&dateToYear=2017\&dateToHour=23 } \\
\text { \&dateToMinute=59\&dateToSecond=59\&authors=\&abstract=\&galleyFullT } \\
\text { ext=\&suppFiles=\&discipline=\&subject=\&type=\&coverage=\&indexTerms } \\
=\end{array}$ \\
\hline
\end{tabular}

Table 2. Number of Research Papers found per Digital Library and Search URL.

The inclusion criteria established for this mapping were: papers that report the conduction of actions (e.g. workshops, courses) to promote CT in any context. The exclusion criterion defined for this mapping are those presented below:

- EC1: Papers that were not written in English or Portuguese.

- EC2: Papers not available for full access.

- EC3: Duplicate research (when two or more papers were describing the same initiative, the most recent or complete one was kept).

3 Available at: https://dl.acm.org/dl.cfm

4 Available at: https://ieeexplore.ieee.org

5 Available at: https://www.springer.com/

6 Available at: https://www.br-ie.org/pub/index.php/index/search 
- EC4: Papers that report teachers who were instructed to apply activities related to $\mathrm{CT}$.

- EC5: Papers describing initiatives of any nature that do not characterize practical interventions with students.

The first filter was based on the papers' titles and abstracts. After the application of the exclusion criterion, 222 papers remained in the sample, being 118 from ACM, 44 from IEEE, 31 from Springer and 29 from CEIE. The second filter examined papers' body content, and the 222 remaining papers were read fully. After the application of the exclusion criterion, 62 papers were selected for further analysis, in which 33 were from ACM, 10 from IEEE, 2 from Springer and 17 from CEIE.

In the third filter, there was the application of quality criteria, aiming to keep only the papers that allowed analysis and answer of research questions. As the objective of this mapping was to select papers that describe initiatives performed to promote CT, the ones that did not characterize the activities, making it impossible to understand, extract the data and replicate the same activity in other contexts, were dismissed. The final sample consisted of 46 papers, 23 from ACM, 8 from IEEE, 2 from Springer and 13 from CEIE.

With the selection phase concluded, we proceeded to the data extraction, for which an extraction template was developed containing the questions and pre-formatted answers, to standardize and facilitate the process. The link to the extraction table is provided in the next chapter.

\section{Results}

The extraction table containing all the papers in the final sample, with their respective ID, title, year of publication, among other information, is available online ${ }^{7}$. A simplified version of this table, with ID, year of publication, paper's title and authors is available in Appendix A. To facilitate papers identification in the answers to the research questions, papers will be referenced by their respective ID.

\section{RQ1: Which countries stood out in the number of initiatives?}

The number of papers published per country has been counted to identify which countries stood out in the conduction of initiatives. As in this mapping, both international and national digital libraries were included, only accepting papers written in English or Portuguese, the countries in which these are the main language could have a greater number of publications than others. Table 3 shows the number of papers published per country.

We identified 13 papers in Portuguese and 33 papers in English. Data shows that the United States and Brazil are the countries that stood out in the number of papers. So, as they are the Top 2 countries in this mapping, for the next question on, a comparison between the initiatives conducted by Brazilian and American researchers will be presented.

During the observed period (2007-2017), only 5 papers were published by researchers from different countries together [18, 26, 27, 28 and 38] and, in these cases,

7 Available at: https://bit.ly/3b6HjUx 
the papers were counted for all participating countries, which is why the number of papers in Table 3 exceeds the number of selected papers (46).

\begin{tabular}{|l|c|}
\hline Country & Number of Research Papers \\
\hline United States of America & 21 \\
\hline Brazil & 15 \\
\hline Italy & 4 \\
\hline Spain & 3 \\
\hline Germany & 2 \\
\hline $\begin{array}{l}\text { Argentina, Canada, Chile, Scotland, India, } \\
\text { Israel, and Taiwan }\end{array}$ & 1 each \\
\hline
\end{tabular}

Table 3. Number of Research Papers Published per Country.

\section{RQ2: Is the interest in conducting initiatives to develop CT growing?}

If we consider that the number of publications demonstrates the interest of the research community on the topic, we can answer yes. Table 4 presents an overview of the number of papers according to their year of publication.

Analyzing the last three years, it is possible to observe that in 2015 the number of publications had a significant increase, in comparison to the year before. In 2016, the number increased again, and in 2017 it had remained almost the same. As this mapping was carried out in November of 2017 and the papers are indexed after their publications, it is possible that the number of papers published in 2017 be higher than what is being presented in this paper.

\begin{tabular}{|c|c|c|c|c|c|c|c|c|c|c|c|}
\hline Year & $\mathbf{2 0 0 7}$ & $\mathbf{2 0 0 8}$ & $\begin{array}{c}\mathbf{2 0 0} \\
\mathbf{9}\end{array}$ & $\mathbf{2 0 1 0}$ & $\mathbf{2 0 1 1}$ & $\begin{array}{c}\mathbf{2 0 1} \\
\mathbf{2}\end{array}$ & $\mathbf{2 0 1 3}$ & $\mathbf{2 0 1 4}$ & $\mathbf{2 0 1 5}$ & $\begin{array}{c}\mathbf{2 0 1} \\
\mathbf{6}\end{array}$ & $\mathbf{2 0 1 7}$ \\
\hline USA & - & - & 2 & 1 & 4 & 2 & 3 & 2 & 3 & 2 & 2 \\
\hline Brazil & - & - & - & - & - & - & - & - & 4 & 6 & 5 \\
\hline $\begin{array}{c}\text { All } \\
\text { initiatives }\end{array}$ & - & - & 2 & 1 & 4 & 2 & 3 & 2 & 9 & 15 & 14 \\
\hline
\end{tabular}

Table 4. Number of Research Papers per Year.

The data also shows that, even though this mapping had searched for papers published since 2007, the oldest paper selected dates back to 2009, which indicates that initiatives to promote CT, specifically using this name, is still in its first decade. As the term "Computational Thinking" has become known only after 2006, it is not possible to 
declare that before that there were no initiatives to promote this skill, as they may have been published under other names.

Since the very first initiative to promote CT in each country, both Brazil and the United States have continued to publish annually. The average number of publications by authors of U.S. institutions is between 2 and 3 papers per year, while the Brazilian rate is close to 5 papers per year, indicating that CT has attracted the focus of researchers in both countries.

\section{RQ3: Which students' educational levels are being addressed by these initiatives?}

There was not a pattern in the specification of this information, so the answers were normalized and categorized according to age and school level. Table 5 shows the defined categories and the respective number of initiatives that have addressed each one of them. Data shows that almost 70\% (32) of the initiatives focused on Elementary and High School. There are several possible reasons for this scenario, such as ease of access to this public, government's incentive, and ease of dealing with children.

Table 5 also presents the Brazilian and American scenario of initiatives. Brazil stood out for focusing almost $100 \%$ of its efforts on Elementary and High School education, while the U.S. has addressed a greater diversity of audiences. The Youth and Adults Education modality was considered by only one research developed in Brazil and no initiatives focusing on equivalent audiences in other countries were identified.

\begin{tabular}{|l|c|c|c|}
\hline \multicolumn{1}{|c|}{ Students' Education Levels } & All initiatives & USA & Brazil \\
\hline Elementary and High school & 32 & $48 \%(10)$ & $\mathbf{9 3 \%}(\mathbf{1 4})$ \\
\hline $\begin{array}{l}\text { Under graduation courses in Computer Science related } \\
\text { field }\end{array}$ & 4 & $19 \%(4)$ & - \\
\hline Under graduation and graduation courses in other fields & 9 & $33 \%(7)$ & - \\
\hline Youth and Adults Education & 1 & - & $7 \%(1)$ \\
\hline
\end{tabular}

Table 5. Number of Research Papers per Students' Education Levels.

Each category and its respective research IDs are: Elementary school: [9, 12, 16, 18, 22, 23, 24, 27, 28, 31, 32, 34, 35, 37, 38, 41, 42, 43, 45 and 46], High school: [14, 15, 17, 19, 20, 21, 29 and 33], Elementary and High school together: [11, 27, 40 and 45], under graduation courses in Computer Science related field: [6, 7, 8 and 11], under graduation and graduation courses in other fields: [1, 2, 3, 4, 5, 13, 25, 36 and 40] and Youth and Adults Education: [30].

\section{RQ4: Are the initiatives addressing students in challenging contexts?}

Only 8 of the selected papers mention the involvement of students in challenging contexts. We cannot state that the other 38 initiatives did not involve students in this condition, only that this information was not in the papers. Table 6 shows the challenging contexts addressed and the number of papers that mentions each one of them. 
Table 6 also presents the scenario found in the United States and Brazil. It turns out that 7 out of the 8 research that had addressed challenging contexts' students are Brazilian or American. This circumstance may demonstrate: a) a greater rigor in the description of initiatives by those countries or b) greater responsibility to consider underrepresented audiences. In any case, less than $20 \%$ of the initiatives involved students in challenging contexts, which demonstrate the need for efforts in this direction.

\begin{tabular}{|l|c|c|c|}
\hline Challenging contexts addressed by initiatives & $\begin{array}{c}\text { All } \\
\text { initiatives }\end{array}$ & USA & Brazil \\
\hline Autism Spectrum Disorder & 1 & - & $6,5 \%(1)^{8}$ \\
\hline Asperger's Syndrome, cerebral palsy, or dyslexia & 1 & $5 \%(1)$ & - \\
\hline Family financial and social limitations & 4 & $10 \%(2)$ & $6,5 \%(1)$ \\
\hline $\begin{array}{l}\text { Students from rural regions or who live at a considerable } \\
\text { distance from school }\end{array}$ & 2 & $10 \%(2)$ & - \\
\hline Papers that does not mention students in challenging contexts & 38 & $76 \%(16)$ & $87 \%(13)$ \\
\hline
\end{tabular}

Table 6. Number of Initiatives per Challenging Contexts Addressed.

Each category and its respective research IDs are: students with Autism Spectrum Disorder: [28], students with Asperger's Syndrome, cerebral palsy or dyslexia: [10], family financial and social limitations: [5, 18, 30 and 43], and students from rural regions or who live at a considerable distance from school: [34 and 35].

\section{RQ5: What contents were developed with $\mathrm{CT}$ in the activities conducted?}

Aware of the transdisciplinary nature of CT, many initiatives had explored multiple contents in the activities conducted. Table 7 presents the contents found and the number of papers that mention each one of them. To a better representation, the subjects related to Computer Science disciplines, such as database and programming were grouped, and activities involving general preferences and knowledge, like soccer teams, weather forecasts, and preferred stores, were named "multidisciplinary activities".

\begin{tabular}{|l|c|c|c|}
\hline Contents involved & $\begin{array}{c}\text { All } \\
\text { initiatives }\end{array}$ & USA & Brazil \\
\hline Computer Science related topics & 21 & $14 \%(3)$ & $\mathbf{6 0} \%(\mathbf{9})$ \\
\hline Game development & 4 & - & $27 \%(4)$ \\
\hline
\end{tabular}

8 This research had the participation of Brazilian and Chilean researchers. Evidence shows that it was conducted in Chile and, therefore, does not counter into the statistics of research involving Brazilian students in challenging contexts. 


\begin{tabular}{|l|c|c|c|}
\hline Mathematics & 4 & $5 \%(1)$ & $6,5 \%(1)$ \\
\cline { 1 - 3 } Multidisciplinary activities & 4 & $5 \%(1)$ & $6,5 \%(1)$ \\
\hline Science & 3 & & \\
\cline { 1 - 2 } Bioinformatics, Physics, Chemistry, Music and Engineering & 2 each & $\mathbf{7 6 \%}(16)$ & - \\
\cline { 1 - 2 } $\begin{array}{l}\text { Architecture, Arts, Biology, Business, Geometry, } \\
\text { Journalism, Gerontology and English Literature }\end{array}$ & 1 each & & \\
\hline
\end{tabular}

Table 7. Number of Research Papers per Contents.

Table 7 also shows a comparison between the research conducted in Brazil and the USA. A total of $76 \%$ of the American initiatives focused on exploring CT across many subjects, reinforcing the multidisciplinary nature of this ability, while the Brazilian research focused on exploring Computer Science core related subjects, such as game development.

Each content found and their respective research IDs are: Computer Science related subjects: $[6,10,12,15,19,21,22,23,24,25,26,28,29,30,31,33,36,37,38$, 43 and 44], game development: [33, 40, 42 and 43], multidisciplinary activities: [11, 16, 45 and 46], Mathematics: [13, 16, 20 and 34], Sciences: [16, 34 and 35], Bioinformatics: [1 and 2], Physics: [1 and 14], Chemistry: [1 and 14], Music: [3 and 14], Engineering: [7 and 34], Architecture: [40], Arts: [18], Biology: [27], Business: [8], Geometry: [9], Journalism: [5], Gerontology: [4] and English Literature: [17].

\section{RQ6: What tools were used in the activities?}

We have observed that many different tools were used throughout the initiatives, $43 \%$ of the papers mention the involvement of two tools or more, and 2 papers do not present any information about this topic. Table 8 presents the tools that have been used more than once in the initiatives.

\begin{tabular}{|l|c|c|c|}
\hline \multicolumn{1}{|c|}{ Tools used } & $\begin{array}{c}\text { All } \\
\text { initiatives }\end{array}$ & USA & Brazil \\
\hline Computer Science Unplugged & 16 & $24 \%(5)$ & $\mathbf{6 0 \%}(\mathbf{9})$ \\
\hline Scratch & 12 & $19 \%(4)$ & $40 \%(6)$ \\
\hline Robotics Kits & 8 & $19 \%(4)$ & $13 \%(2)$ \\
\hline Code.org & 3 & - & $13 \%(2)$ \\
\hline LightBot & 2 & - & $13 \%(2)$ \\
\hline Other tools & 26 & $\mathbf{7 0 \% ( 1 4 )}$ & $27 \%(4)$ \\
\hline
\end{tabular}

Table 8. Number of Research Papers per Tools Used.

Table 8 also shows the scenario of initiatives conducted in Brazil and the USA. In the United States, we observed a greater diversity of tools, possibly because they 
have explored the transdisciplinary potential of CT. Towards Brazil, we observed a great use of Computer Science Unplugged, in some cases preceding other tools. In these situations, researchers can use a lot of creativity to involve students in learning dynamics without worrying about issues of technical infrastructure or a possible resistance of students to use the computer. In countries like Brazil, where sometimes schools do not have adequate infrastructure to support initiatives involving technology, the potential of this tool is even more singular.

The initiatives that had used each tool respectively were: Computer Science Unplugged: [6, 9, 10, 14, 15, 16, 17, 22, 30, 32, 38, 39, 41, 42, 44 and 45], Scratch: [3, 5, 12, 16, 19, 20, 22, 25, 28, 30, 45 and 46], Robotics kits: [10, 12, 13, 23, 24, 29, 34, and 44], Code.org: [30, 37 and 41] and LightBot: [30 e 39].

\section{RQ7: How long were the initiatives conducted with the students?}

Since there was no pattern to describe the duration of each initiative, to answer this question the extracted data had been normalized and separated into categories. Some papers describe the duration in hours, others in classes or even weeks, and 5 papers do not specify this information.

Table 9 shows the number of research papers found by the categories, in which it is possible to observe a variation in the duration of the initiatives, and also presents a comparison between the Brazilian and American scenario, in which it is possible to observe that $53 \%$ of the U.S. initiatives had lasted for 1 semester or more, while most of the Brazilian initiatives lasted for 4 to 7 classes.

The papers that have reported each duration category respectively are: 1-3 classes: [9, 18 and 39], 4-7 classes: [10, 12, 15, 20, 21, 26, 27, 29, 30, 32 and 43], 8-15 classes: [23 and 28], 2-4 weeks: [5, 33 and 35], 5-7 weeks: [31, 36 and 38], 8-15 weeks: $[11,22,25,34,45$ and 46], 1 semester: $[1,2,3,4,6,7,8,13,17,19,40$ and 42] and 1 year: [16].

\begin{tabular}{|l|c|c|c|}
\hline Initiatives duration & $\begin{array}{c}\text { All } \\
\text { initiatives }\end{array}$ & USA & Brazil \\
\hline $1-3$ classes & 3 & $10 \%(2)$ & $7 \%(1)$ \\
\hline $4-7$ classes & 11 & $14 \%(3)$ & $\mathbf{3 3 \%}(\mathbf{5})$ \\
\hline $8-15$ classes & 2 & - & $7 \%(1)$ \\
\hline 2-4 weeks & 3 & $10 \%(2)$ & - \\
\hline $5-7$ weeks & 3 & - & $13 \%(2)$ \\
\hline $8-15$ weeks & 6 & $10 \%(2)$ & $13 \%(2)$ \\
\hline 1 semester & 12 & $\mathbf{4 8 \% ( 1 0 )}$ & $13 \%(2)$ \\
\hline 1 year & 1 & $\mathbf{5 \% ( 1 )}$ & - \\
\hline
\end{tabular}

Table 9. Number of Research Papers per Initiatives Duration.

\section{Discussion}


The data obtained and the research questions answered to characterize the scenario reflect the digital libraries where the papers were found and need to be understood within the defined scope for this study. A table containing the extracted data is available to be audited and verified by the reader, allowing an extension of this study to other digital libraries or longer periods of search.

According to the data, it is possible to observe that when it comes to practical initiatives, CT as a field is still in its first decade of research, even in the international scenario. In Brazil, initiatives to teach CT are even newer, dating back to 2015. Although recent, Brazil has already published a great number of papers, and maintained a high number of annual publications, revealing Brazilian researchers' interest in this topic.

However, although Brazil has achieved more than $70 \%$ of the number of American initiatives, comparing the characteristics between the initiatives in both countries it is possible to observe research trends: while Brazilian research seems to follow the pattern of other countries with a smaller number of initiatives, American research is conducted differently regarding the examined aspects. For example, American research explored other subjects/contents outside the Computer Science core; also explored different tools, greater diversity of students' educational levels addressed, and longer initiatives in comparison with other countries.

Among Brazilian research, we found almost all of the initiatives focusing on students from Elementary and High School education, in which the only one carried out with a different audience involved Youth and Adults Education; computer science unplugged was greatly used, many times due to (lack of) infrastructure; the initiatives were shorter and there was no initiative exploring CT with subjects besides the ones related to Computer Science, such as Mathematics and Game Development. CT can be used to solve problems from different natures, and so can be a useful skill for everyone, not only computer scientists. Thus, according to this mapping, we identify as CT research opportunities in Brazil: to address students from different educational levels, explore CT's transdisciplinarity, and to carry out longer initiatives, to better comprehend students' performance and the activities' potential.

Furthermore, it seems that students in challenging contexts were ignored by Brazilian and international initiatives, which reveals more than an opportunity, but a responsibility. Specifically in Brazil, even though the challenging socioeconomic context is recognized, only one paper mentions the participation of Brazilian students in a challenging social-economic context (Youth and Adults Education).

One possible explanation for this scenario could be that the challenging aspects of the participants, and how initiatives to develop CT could be even more life-changing to them are not being highlighted by the authors. As Brazil is a country with a greatly diverse population, and as it is a Great Challenge of Computer Research to overcome technological, educational, cultural, social and economic barriers to enable participatory and universal access of knowledge by Brazilian citizens, see Challenge \#4 ${ }^{9}$ (SBC, 2006) there is a need to intensify research efforts by the Brazilian Computer Science community in the context of this challenge. CT has great potential to contribute to the digital inclusion of people (Ortiz et al., 2019). Initiatives to promote and practice CT skills in a contextualized way conceived to foster the empowerment of people to

9 The scope of the Great Challenges of Computer Research in Brazil proposed by SBC was from 2006 to 2016. Recognizing the relevance of Challenge \#4, Participatory and Universal Access of the Brazilian Citizen to Knowledge, the Brazilian HCI community extended the scope of this challenge to 2012-2022 with GranDIHC-BR. Technical Report available at: http://comissoes.sbc.org.br/ce-ihc/wpcontent/uploads/2017/10/rt_great_challenges_ihc_2012.pdf?x70287 
recognize and act in their reality to solve their problems may contribute to advance in Challenge \#4, as they could provide students with ways to effectively participate in the generation of their knowledge.

Finally, our recommendation for further $\mathrm{CT}$ research for all countries is to describe the initiatives with rigor, enabling, for example, the understanding of the research scenario and the students' contexts, to allow the reproducibility of the experiment, or parts of it, as activities.

\section{Conclusion}

Since 2006, CT as a reasoning ability has raised researchers' interest all over the world, and several initiatives are annually being carried out to further develop this ability with students. This research's goal was to outline the scenario of these initiatives conducted inside and outside Brazil, seeking to identify trends and research opportunities. Therefore, a systematic mapping study was carried out to answer seven research questions as to how long the initiatives were conducted with the students and which educational levels are being addressed by the initiatives. From an initial set of 468 papers, after the application of exclusion and quality criterion, 46 papers were selected.

The data extracted from the selected papers shows that practical initiatives to promote CT are still recent, dating back to 2009. Because of the languages selected for this mapping study, the USA and Brazil were the countries that stood out in the number of research, however, several differences were found when comparing Brazilian and American initiatives.

In Brazil, although the first paper found dates back to 2015, indicating an initial stage of research on this topic, it is already possible to observe an expressive number of publications, demonstrating that the Brazilian researchers have been advancing in the area. However, even though the socio-economic context is a major challenge in Brazil, it has not yet been possible to identify whether the Brazilian Computer community has been directing research efforts in challenging contexts.

As an opportunity to be explored by CT development research in Brazil, we recommend: addressing audiences other than Elementary and High School, exploring CT's trans-disciplinarity across multiple subjects, carrying out longer initiatives, and addressing students in challenging contexts.

\section{Acknowledgements}

This paper is a translated, extended, and revised version of a paper entitled (in Portuguese) "Um Mapeamento Sistemático Sobre as Iniciativas para Promover o Pensamento Computacional" published at the XXIX Brazilian Symposium on Informatics in Education (SBIE 2018). The authors thank the Editors for the invitation. This paper is partially supported by the Coordination for the Improvement of Higher Education Personnel - Brazil (CAPES) - Financing Code 001.

\section{References}

AVILA, C., CAVAlheiro, S., BORdini, A., MARQUES, M., CARdoso, M.; FEIJÓ, G. (2017). Metodologias de Avaliação do Pensamento Computacional: uma 
revisão sistemática. Anais do XXVIII Simpósio Brasileiro de Informática na Educação (SBIE 2017). Vol. 28, No. 1, p. 113.

BARR, V.; STEPHENSON, C., Computational thinking to k-12: What is involved and what is the role of the computer science education community? ACM Inroads, v. 2, n. 1, p. 48-54, 2011.

BORDINI, A.; AVILA, C.; MARQUES, M.; FOSS, L.; CAVALHEIRO, S. (2017). Pensamento Computacional nos Ensinos Fundamental e Médio: uma revisão sistemática. In Anais do XXVIII Simpósio Brasileiro de Informática na Educação (SBIE 2017). Vol. 28, No. 1, p. 123.

CARVALHO, J.; NETTO, J. F.; ALMEIDA, T. (2017). Revisão Sistemática de Literatura sobre Pensamento Computacional por Meio de Objetos de Aprendizagem. In Anais do XXVIII Simpósio Brasileiro de Informática na Educação (SBIE 2017). Vol. 28, No. 1, p. 223.

LIZ, A.; OLIVEIRA DE ARAÚJO, S.; ANDRADE, W. L.; SEREY GUERRERO, D. D. (2017). Um Mapeamento Sistemático sobre a Avaliação do Pensamento Computacional no Brasil. In Anais dos Workshops do V Congresso Brasileiro de Informática na Educação (CBIE 2016). Vol. 5, No. 1, p. 1147.

ORTIZ, J.; JUNIOR, D. S.; OLIVEIRA, C. M.; \& PEREIRA, R. (2019, November). Pensamento Computacional e Cultura Digital: discussões sobre uma prática para o letramento digital. In Simpósio Brasileiro de Informática na Educação - (SBIE 2019) Vol. 30, No. 1, p. 1241.

PAPERT, S. (1980). Mindstorms: Children, Computers, and Powerful Ideas. Basic Books.

PETERSEN, K.; VAKKALANKA, S.; KUZNIARZ, L., Guidelines for Conducting Systematic Mapping Studies in Software Engineering: An update. Information and Software Technology, vol. 64, RQ 1-18, 2015.

SBC, Grandes Desafios da Pesquisa em Computação no Brasil-2006-2016: relatório sobre o seminário realizado em 8 e 9 de maio de 2006. SBC, p. 26, 2006.

WING, J. M. Computational thinking. Communications of the ACM, vol. 49, no. 3, RQ 33-35, 2006.

YADAV, A.; STEPHENSON, C.; HONG, H., Computational thinking for teacher education. Communications of the ACM, v. 60, n. 4, p. 55-62, 2017.

ZANETTI, H.; BORGES, M.; RICARTE, I., (2016) Pensamento Computacional no Ensino de Programação: Uma Revisão Sistemática da Literatura Brasileira. In Anais do XXVII Simpósio Brasileiro de Informática na Educação (SBIE 2016). Vol. 27, No. 1, p. 21.

\section{Appendix A - Research Papers Mapped}

\begin{tabular}{|c|c|c|c|c|}
\hline I & $\begin{array}{c}\text { Yea } \\
\text { D }\end{array}$ & $\begin{array}{c}\text { Digital } \\
\text { library }\end{array}$ & Paper Title & Authors \\
\hline 1 & 2009 & ACM & A Multidisciplinary Approach Towards & Hambrusch, S., Hoffmann, C., Korb, \\
\hline
\end{tabular}




\begin{tabular}{|c|c|c|c|c|}
\hline & & & Computational Thinking for Science Majors & $\begin{array}{l}\text { J. T., Haugan, M., and Hosking, A. } \\
\text { L. }\end{array}$ \\
\hline 2 & 2009 & $\mathrm{ACM}$ & $\begin{array}{l}\text { Teaching Computational Thinking Through } \\
\text { Bioinformatics to Biology Students }\end{array}$ & Qin, $\mathrm{H}$. \\
\hline 3 & 2010 & $\mathrm{ACM}$ & $\begin{array}{l}\text { Teaching Computational Thinking Through } \\
\text { Musical Live Coding in Scratch }\end{array}$ & $\begin{array}{l}\text { Ruthmann, A., Heines, J. M., Greher, } \\
\text { G. R., Laidler, P., and Saulters, II, C. }\end{array}$ \\
\hline 4 & 2011 & IEEE & $\begin{array}{l}\text { A novel interdisciplinary course in } \\
\text { gerontechnology for disseminating computational } \\
\text { thinking }\end{array}$ & $\begin{array}{l}\text { Yang, H. I., Martin, P., Satterfield, } \\
\text { D., Babbitt, R., Wong, J., Shelley, } \\
\text { M., and Chang,C. K. }\end{array}$ \\
\hline 5 & 2011 & $\mathrm{ACM}$ & $\begin{array}{l}\text { Computational Thinking and Expository Writing in } \\
\text { the Middle School }\end{array}$ & $\begin{array}{l}\text { Wolz, U., Stone, M., Pearson, K., } \\
\text { Pulimood, S. M., and Switzer, M. }\end{array}$ \\
\hline 6 & 2011 & $\mathrm{ACM}$ & $\begin{array}{l}\text { CS1 Students' Understanding of Computational } \\
\text { Thinking Concepts }\end{array}$ & $\begin{array}{l}\text { A. Qualls, J., Grant, M., and Sherrell, } \\
\text { L. }\end{array}$ \\
\hline 7 & 2011 & $\mathrm{ACM}$ & $\begin{array}{l}\text { Initial Experience with a Computational Thinking } \\
\text { Course for Computer Science Students }\end{array}$ & Kafura, D. and Tatar, D. \\
\hline 8 & 2012 & $\mathrm{ACM}$ & $\begin{array}{l}\text { IT Problem Solving: An Implementation of } \\
\text { Computational Thinking in Information } \\
\text { Technology }\end{array}$ & $\begin{array}{l}\text { L'Heureux, J., Boisvert, D., Cohen, } \\
\text { R., and Sanghera, K. }\end{array}$ \\
\hline 9 & 2012 & $\mathrm{ACM}$ & $\begin{array}{l}\text { Math on a Sphere: Using Public Displays to } \\
\text { Support Children's Creativity and Computational } \\
\text { Thinking on 3D Surfaces }\end{array}$ & Hsi, S. and Eisenberg, M. \\
\hline 10 & 2013 & $\mathrm{ACM}$ & $\begin{array}{l}\text { Accelerating K-12 Computational Thinking Using } \\
\text { Scaffolding, Staging, and Abstraction }\end{array}$ & $\begin{array}{l}\text { Touretzky, D. S., Marghitu, D., Ludi, } \\
\text { S., Bernstein, D., and Ni, L. }\end{array}$ \\
\hline 11 & 2013 & IEEE & $\begin{array}{l}\text { Improving learning of computational thinking using } \\
\text { creative thinking exercises in CS-1 computer } \\
\text { science courses }\end{array}$ & $\begin{array}{l}\text { Miller, L. D., Soh, L. K., } \\
\text { Chiriacescu, V., Ingraham, E., Shell, } \\
\text { D. F., Ramsay, S., and Hazley, M. P. }\end{array}$ \\
\hline 12 & 2013 & $\mathrm{ACM}$ & $\begin{array}{l}\text { Using Scaffolded Examples to Teach } \\
\text { Computational Thinking Concepts }\end{array}$ & Webb, H. and Rosson, M. B. \\
\hline 13 & 2014 & $\mathrm{ACM}$ & $\begin{array}{l}\text { Effectiveness of a Computational Thinking (CS0) } \\
\text { Course on Student Analytical Skills }\end{array}$ & Van Dyne, M. and Braun, J. \\
\hline 14 & 2014 & IEEE & $\begin{array}{l}\text { Introducing computational thinking through stealth } \\
\text { teaching }\end{array}$ & $\begin{array}{l}\text { Towhidnejad, M., Kestler, C., Jafer, } \\
\text { S., and Nicholas, V. }\end{array}$ \\
\hline 15 & 2015 & CEIE & $\begin{array}{l}\text { Desenvolvimento do Pensamento Computacional: } \\
\text { um relato de atividade junto ao Ensino Médio, } \\
\text { através do Estágio Supervisionado em Computação } \\
\text { III }\end{array}$ & Hinterholz, L. and da Cruz, M. K. \\
\hline 16 & 2015 & IEEE & $\begin{array}{l}\text { DISSECT: An experiment in infusing } \\
\text { computational thinking in a sixth grade classroom }\end{array}$ & Peel, A., Fulton, J., and Pontelli, E. \\
\hline 17 & 2015 & IEEE & $\begin{array}{l}\text { DISSECT: Exploring the relationship between } \\
\text { computational thinking and English literature in K- } \\
12 \text { curricula }\end{array}$ & $\begin{array}{l}\text { Nesiba, N., Pontelli, E., and Staley, } \\
\text { T. }\end{array}$ \\
\hline 18 & 2015 & $\mathrm{ACM}$ & $\begin{array}{l}\text { From Computational Thinking to Computational } \\
\text { Making }\end{array}$ & $\begin{array}{l}\text { Rode, J. A., Weibert, A., Marshall, } \\
\text { A., Aal, K., von Rekowski, T., El } \\
\text { Mimouni, H., and Booker, J. }\end{array}$ \\
\hline
\end{tabular}




\begin{tabular}{|c|c|c|c|c|}
\hline 19 & 2015 & CEIE & $\begin{array}{l}\text { Pensamento Computacional: transformando ideias } \\
\text { em jogos digitais usando o Scratch }\end{array}$ & $\begin{array}{l}\text { Rodriguez, C., Zem-Lopes, A. M., } \\
\text { Marques, L., and Isotani, S. }\end{array}$ \\
\hline 20 & 2015 & CEIE & $\begin{array}{l}\text { Significação da Aprendizagem Através do } \\
\text { Pensamento Computacional no Ensino Médio: uma } \\
\text { Experiência com Scratch }\end{array}$ & Ramos, F. and Teixeira, L. D. S. \\
\hline 21 & 2015 & $\mathrm{ACM}$ & $\begin{array}{l}\text { Students Want to Create Apps: Leveraging } \\
\text { Computational Thinking to Teach Mobile Software } \\
\text { Development }\end{array}$ & Fronza, I., El Ioini, N., and Corral, L. \\
\hline 22 & 2015 & CEIE & $\begin{array}{l}\text { Uma Experiência no Ensino de Pensamento } \\
\text { Computacional para Alunos do Ensino } \\
\text { Fundamental }\end{array}$ & $\begin{array}{l}\text { Schoeffel, P., Moser, P., Varela, G., } \\
\text { Durigon, L., de Albuquerque, G. C., } \\
\text { and Niquelatti, M. }\end{array}$ \\
\hline 23 & 2016 & IEEE & $\begin{array}{l}\text { An Experience Report on Teaching Programming } \\
\text { and Computational Thinking to Elementary Level } \\
\text { Children Using Lego Robotics Education Kit }\end{array}$ & $\begin{array}{l}\text { Chaudhary, V., Agrawal, V., Sureka, } \\
\text { P., and Sureka, A. }\end{array}$ \\
\hline 24 & 2016 & CEIE & $\begin{array}{l}\text { Aplicação de Robótica na Educação de Forma } \\
\text { Gradual para o Estímulo do Pensamento } \\
\text { Computacional }\end{array}$ & $\begin{array}{l}\text { da Silva, D. P., Sidnei, S., Jesus, A., } \\
\text { and Silva, C. E. P. }\end{array}$ \\
\hline 25 & 2016 & $\mathrm{ACM}$ & Computational Thinking As a Liberal Study & $\begin{array}{l}\text { Mason, D., Khan, I., and Farafontov, } \\
\text { V. }\end{array}$ \\
\hline 26 & 2016 & Springer & $\begin{array}{l}\text { Developing Computational Thinking Abilities } \\
\text { Instead of Digital Literacy in Primary and } \\
\text { Secondary School Students }\end{array}$ & $\begin{array}{l}\text { Segredo, E., Miranda, G., León, C., } \\
\text { and Santos, A. }\end{array}$ \\
\hline 27 & 2016 & $\mathrm{ACM}$ & $\begin{array}{l}\text { Frogs to Think with: Improving Students' } \\
\text { Computational Thinking and Understanding of } \\
\text { Evolution in A Code-First Learning Environment }\end{array}$ & $\begin{array}{l}\text { Guo, Y., Wagh, A., Brady, C., Levy, } \\
\text { S. T., Horn, M. S., and Wilensky, U. }\end{array}$ \\
\hline 28 & 2016 & IEEE & $\begin{array}{l}\text { Game design workshop to develop computational } \\
\text { thinking skills in teenagers with Autism Spectrum } \\
\text { Disorders }\end{array}$ & $\begin{array}{l}\text { Munoz, R., Barcelos, T. S., } \\
\text { Villarroel, R., and Silveira, I. F. }\end{array}$ \\
\hline 29 & 2016 & CEIE & $\begin{array}{l}\text { Pensamento Computacional e Robótica: Um Estudo } \\
\text { Sobre Habilidades Desenvolvidas em Oficinas de } \\
\text { Robótica Educacional }\end{array}$ & Oliveira, E. and Araujo, A. L. \\
\hline 30 & 2016 & CEIE & $\begin{array}{l}\text { Pensamento Computacional na Educação de Jovens } \\
\text { e Adultos: Lições Aprendidas }\end{array}$ & Ortiz, J. B. and Raabe, A. \\
\hline 31 & 2016 & CEIE & $\begin{array}{l}\text { Pensamento Computacional no Ensino } \\
\text { Fundamental: Relato de Atividade de Introdução a } \\
\text { Algoritmos }\end{array}$ & $\begin{array}{l}\text { Pinho, G., Weisshahn, Y., Reiser, R., } \\
\text { de Brum, C. F., Cavalheiro, S., Foss, } \\
\text { L., Aguiar, M., and Bois, A. D. }\end{array}$ \\
\hline 32 & 2016 & CEIE & $\begin{array}{l}\text { Proposta de Jogo Digital para Dispositivos Móveis: } \\
\text { Desenvolvendo Habilidades do Pensamento } \\
\text { Computacional }\end{array}$ & $\begin{array}{l}\text { Pinho, G., Weisshahn, Y., de Brum, } \\
\text { C. F., Cavalheiro, G. G. H., and } \\
\text { Cavalheiro, S. }\end{array}$ \\
\hline 33 & 2016 & $\mathrm{ACM}$ & $\begin{array}{l}\text { Teaching High School Students Computational } \\
\text { Thinking with Hands-on Activities }\end{array}$ & Li, W.-L., Hu, C.-F., and Wu, C.-C. \\
\hline 34 & 2016 & Springer & $\begin{array}{l}\text { Using Robotics and Game Design to Enhance } \\
\text { Children's Self-Efficacy, STEM Attitudes, and } \\
\text { Computational Thinking Skills }\end{array}$ & $\begin{array}{l}\text { Leonard, J., Buss, A., Gamboa, R., } \\
\text { Mitchell, M., Fashola, O. S., Hubert, } \\
\text { T., and Al-mughyirah, S. }\end{array}$ \\
\hline 35 & 2017 & $\mathrm{ACM}$ & $\begin{array}{l}\text { Case for Integrating Computational Thinking and } \\
\text { Science in a Low-Resource Setting }\end{array}$ & $\begin{array}{l}\text { Gautam, A., Bortz, W. E. W., and } \\
\text { Tatar, D. }\end{array}$ \\
\hline
\end{tabular}




\begin{tabular}{|c|c|c|c|c|}
\hline 36 & 2017 & IEEE & $\begin{array}{l}\text { Computational thinking as springboard for learning } \\
\text { object-oriented programming in an interactive } \\
\text { MOOC }\end{array}$ & Krugel, J. and Hubwieser, P. \\
\hline 37 & 2017 & $\mathrm{ACM}$ & $\begin{array}{l}\text { Computational Thinking in Italian Schools: } \\
\text { Quantitative Data and Teachers' Sentiment } \\
\text { Analysis After Two Years of Programma Il Futuro }\end{array}$ & $\begin{array}{l}\text { Corradini, I., Lodi, M., and Nardelli, } \\
\text { E. }\end{array}$ \\
\hline 38 & 2017 & $\mathrm{ACM}$ & $\begin{array}{l}\text { Development of Computational Thinking Skills } \\
\text { Through Unplugged Activities in Primary School }\end{array}$ & $\begin{array}{l}\text { Brackmann, C. P., Román- González, } \\
\text { M., Robles, G., Moreno- León, J., } \\
\text { Casali, A., and Barone,D. }\end{array}$ \\
\hline 39 & 2017 & CEIE & $\begin{array}{l}\text { Estudo Comparativo de Abordagens Referentes ao } \\
\text { Desenvolvimento do Pensamento Computacional }\end{array}$ & $\begin{array}{l}\text { Cândido, D., Pessoa, G., } \\
\text { Vasconcelos, B., da Silva, L. L., } \\
\text { Oliveira, R., Oliveira, M., and } \\
\text { Falcão, T. P. }\end{array}$ \\
\hline 40 & 2017 & $\mathrm{ACM}$ & $\begin{array}{l}\text { Evaluation and Impact of a Required } \\
\text { Computational Thinking Course for Architecture } \\
\text { Students }\end{array}$ & Senske, N. \\
\hline 41 & 2017 & CEIE & $\begin{array}{l}\text { O ensino do pensamento computacional como } \\
\text { forma de inclusão tecnológica e motivação de } \\
\text { crianças }\end{array}$ & Rodrigues, G. and Sousa, L. \\
\hline 42 & 2017 & CEIE & $\begin{array}{l}\text { Pensamento Computacional: Uma Proposta de } \\
\text { Ensino com Estratégias Diversificadas para } \\
\text { Crianças do Ensino Fundamental }\end{array}$ & $\begin{array}{l}\text { Reis, F. D. M., Cristiano, F., Martins, } \\
\text { D., and Rocha, P. D. }\end{array}$ \\
\hline 43 & 2017 & $\mathrm{ACM}$ & $\begin{array}{l}\text { Promoting Computational Thinking and } \\
\text { Creativeness in Primary School Children }\end{array}$ & $\begin{array}{l}\text { Chiazzese, G., Fulantelli, G., } \\
\text { Pipitone, V., and Taibi, D. }\end{array}$ \\
\hline 44 & 2017 & $\mathrm{ACM}$ & $\begin{array}{l}\text { Promoting Computational Thinking in K-12 } \\
\text { Students by Applying Unplugged Methods and } \\
\text { Robotics }\end{array}$ & $\begin{array}{l}\text { Conde, M. A., Fernández-Llamas, C., } \\
\text { Rodríguez-Sedano, F. J., Guerrero- } \\
\text { Higueras, A. M., Matellán-Olivera, } \\
\text { V., and García-Peñalvo, F. J. }\end{array}$ \\
\hline 45 & 2017 & $\mathrm{ACM}$ & $\begin{array}{l}\text { Teaching Computational Thinking Using Agile } \\
\text { Software Engineering Methods: A Framework for } \\
\text { Middle Schools }\end{array}$ & Fronza, I., Ioini, N. E., and Corral, L. \\
\hline 46 & 2017 & CEIE & $\begin{array}{l}\text { Tem Ideia na Rede: Inserindo o Pensamento } \\
\text { Computacional na Rede Municipal de Ensino }\end{array}$ & $\begin{array}{l}\text { Santana, A. L. M., de Jesus, E. A., } \\
\text { Raabe, A., Santana, L., Cucco, L., } \\
\text { and Ramos, G. }\end{array}$ \\
\hline
\end{tabular}

Table 10. Research papers mapped with ID, year of publication, digital library, paper title and authors 